\title{
Habitat Patch Diversity Evaluation for Sustainability: a Case Study of a Rural Area in Central Italy
}

\author{
Roberto Mancinelli, Enio Campiglia*, Fabio Caporali, Vincenzo Di Felice \\ Department of Crop Production, University of Tuscia \\ Via San Camillo De Lellis, 01100 Viterbo, Italy
}

Received: 11 June 2009. Accepted: 28 June 2010.

\begin{abstract}
Landscape analysis is regarded as a new tool for monitoring and judging land use patterns in terms of sustainability of human activity systems at local level. A case study of evaluation for sustainability based on habitat patch diversity in an ecoregion of Central Italy is presented. In this region, ongoing land use patterns reflect both historical adaptation to local environmental constraints and positive, social-oriented management. More protective land use patterns are mostly widespread in fragile physiographic conditions like those of the mountain areas, where woodland, shrub, and grassland patches are larger and cover more than $90 \%$ of the land. This situation is regarded as a positive outcome of the traditional public ownership regime, because public lands amount to more than $70 \%$ in the mountain areas. The hilly areas, where public property drops to $28 \%$, presents landscape metrics showing a well balanced situation between agricultural land use and protective native woods and grasslands, which provides a finegrained and harmonious Mediterranean landscape. In the low-land areas, with anthropic pressure and more favourable conditions for crop productivity, there is much more agricultural land, even if some mitigation in terms of biodiversity maintenance is offered by the presence of hedgerow ecotones. In these areas, landscape analysis is not able to supply meaningful information about cropping system design and practices which can maintain a sustainable level of soil fertility and quality of natural resources and processes, and further analysis at cropping system level should be carried out.
\end{abstract}

Key-words: land use pattern, GIS, biodiversity indicators, landscape metrics.

\section{Introduction}

Sustainable development includes the necessity for humanity to grow food through agriculture as well as to maintain natural environments for ecological services other than food (Daily, 1997). The search for a balance between production and protection in land use is therefore a major challenge to future society at both local and global level. To achieve this goal, it is necessary to establish a responsible culture for sustainability and scientists should play an active role in this process. There is a long tradition in agricultural land use in Europe where the countryside is incomparable to any other countries in the world (Busch, 2006; Hampicke, 2006), current examples of sustainable rural development should be better known explored and spread as meaningful case studies of traditional knowledge and wise land use. Measures taken for reducing the impact of human activities on biodiversity have rarely focused on the management of the problems concerning the various land-use alternatives but these measures have addressed the impact indirectly with for instance legislation for reducing pollution and the establishment of protected areas (Henle et al., 2008). New scientific tools, like those offered by landscape ecology, have the potential to facilitate our understanding of land structure and use. Indeed, landscape ecology was motivated by the new perspective offered by aerial photography (Turner, 2003). With this tool, a landscape can be analyzed and studied as a spatial mosaic or patchiness (Bastin et al., 2002), being the elementary component or landscape ele- 
ment (Burel and Baudry, 2003) that are differentiated by abrupt transition to adjacent areas and by biotic and abiotic structure or composition (Gustafson, 1998; Picket and Cadenasso, 1995). Ecological systems that are spatially heterogeneous can be represented by means of categorical maps that quantify variability by identifying patches (Gustafson, 1998), each one representing a single biotope or habitat. Patches are formed due to persistent differences in environmental resources that lead to a final climax community or in response to natural or human-caused disturbances that change the direction of ecological succession. The spatial pattern of patch creation and the changes within patches constitute patch dynamics (Xu et al., 2006).

Landscape ecology focuses mainly on the reciprocal interactions between spatial patterns and ecological processes, thus the development of pattern metrics has been largely stabilized by evaluating the reciprocal interactions between spatial heterogeneity and ecological processes (Hargis et al., 1998; Li and Wu, 2004; Turner, 2003).

In human-dominated landscapes, a habitat fragmentation process usually takes place (Fahrig, 2003) as a result of human intervention, whereby an original large expanse of natural habitat is transformed into a number of smaller patches isolated from one another by a matrix of habitats which differ from the original habitat. This process involves both the loss and breaking apart of the original habitat as well as the creation of new types of habitats. Quantifying the degree of fragmentation and its ecological implications at landscape level is the main task of landscape ecology.

Agriculture is by no means the most widespread form of man-induced land use change. If it changes original biotopes, e.g. wilderness or naturalness, it can also produce other kinds of semi-natural environments so that the new fragmented habitat can have some positive influences on agroecosystem biodiversity and matter flux control (Duelli, 1997; Ries et al., 2004; Ryszkowki et al., 1999; Tscharntke et al., 2002).

Traditional types of agriculture more tailored to both environmental constraints and local population requirements, are likely to meet sustainability principles more than modern, conventional agriculture (Caporali, 2004; Caporali et al., 2010), where uniformity and homogeneity of large fields of mono-crops are incompat- ible with environmental quality and conservation of biological resources. In the Mediterranean Basin, the development of ecosystems has been so intimately associated with human social systems for so long that the present situation, as shown by landscape patterns, it reflects the organization over-imposed by more or less autonomous rural communities in many cases. In history, local people exploited a wide variety of forest, pasture and ecotone products, and governed themselves in such a way that the biological and landscape diversity was preserved (Caporali et al., 2010).

This paper aims at describing a rural ecoregion in Central Italy through some landscape metrics, which can be regarded as representative of larger areas in Italy (about $280,000 \mathrm{~km}^{2}$ are classified as rural; National Rural Network, 2009) and in the Mediterranean Basin in terms of both biophysical conditions and land-use patterns locally planned and historically developed. Understanding of good land use should help us to strengthen policy and public investment for local capacity building and planning in favour of sustainable development, as required by both the Agenda 21 (UN, 1992) and the recently approved European Landscape Convention.

\section{Material and methods}

\subsection{A profile of the ecoregion}

An ecoregion is defined as a region of relative homogeneity in ecological systems and human factors (Omernik, 1987). The ecoregion we studied is located in Central Italy (Lazio Region) between the Tyrrhenian sea and the Apennine

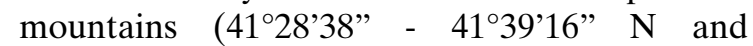
$\left.12^{\circ} 55^{\prime} 00^{\prime \prime}-13^{\circ} 09^{\prime} 51^{\prime \prime} \mathrm{E}\right)$ (Fig. 1). This ecoregion is about $160 \mathrm{~km}^{2}$ and includes three towns with approximately 13,000 inhabitants (81.2 inhabitant $\mathrm{km}^{-2} ; 0.4 \%$ of the national rural villages; $0.4 \%$ of national inhabitants living in rural areas; $0.6 \%$ of the national rural area) which are examples of historical rural settlements, which have existed in Central Italy since medieval times. Its elevation ranges from 10 to $1500 \mathrm{~m}$ a.s.l. where $22 \%$ is low-land (0-200 m a.s.l.), $29 \%$ is hill (200-600 m a.s.l.) and $49 \%$ is mountain (over $600 \mathrm{~m}$ a.s.l.). The microclimate differs mainly according to altimetry and orography, with annual rainfall ranging between 830-1530 


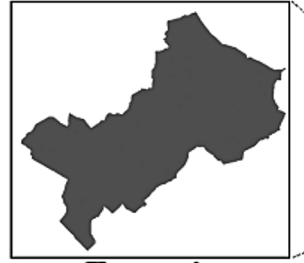

Ecoregion

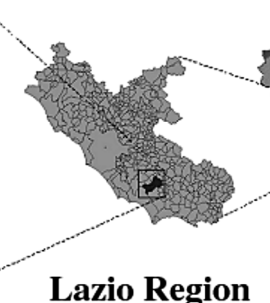

Lazio Region

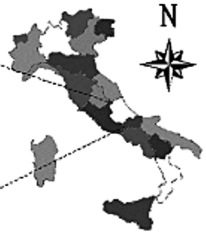

Italy

Figure 1. Ecoregion's location.

mm (divided into 70-80 rainy days/year). Rainfall occurs mainly during the winter (sometimes as snow at high altitudes; average temperature 5-7 ${ }^{\circ} \mathrm{C}$ ). In spring and autumn the availability of water is guaranteed by winter stocks and rainfall (moderate and frequent). Summer is characterized by (average temperature 27-30 ${ }^{\circ} \mathrm{C}$ ), rare rainfall (sometimes violent and the cause of run-off) and high temperatures (above $30{ }^{\circ} \mathrm{C}$ ) which determine water deficit often compromising the crop yields. The air moisture content ranges between 70-90\%. According to geological and lithological studies (Sevink et al., 1984), soils are calcareous in the mountain areas and sedimentary (about $10 \mathrm{~m}$ deeps) in the low-land areas. The Italian Ministry of Environmental Protection classifies about $73 \%$ of the ecoregion as prone to hydro-geological risks, while $27 \%$ of the ecoregion is a protected area according to the "Natura 2000 Networking Programme".

\subsection{Methods used for analyzing the landscape}

The applied methodology was based on the combination of GIS photo-interpretation on high-resolution aerial-photographs $\left(1 \mathrm{~m} \mathrm{pixel}^{-1}\right)$ with cartographic analysis and fieldwork. For the study, all data were directly collected by photo-interpreting a series of high quality images (obtained for the whole of Italian territory for the year 2000). The landscape structure was assessed by studying the ecomosaic composed of landscape elements or patches (Forman 1995a) which according to the European land analysis principles (COoRdination de l'INformation sur l'Environnement program COR.IN.E.), were grouped in the following landscape complexes: herbaceous crops (HC), tree crops $(\mathrm{TC})$, woods $(\mathrm{W})$, hedges $(\mathrm{H})$, grassland $(\mathrm{G})$, shrubs and grasslands (SG), buildings (B), roads (RL) and flowing waters $(\mathrm{FW})$. As

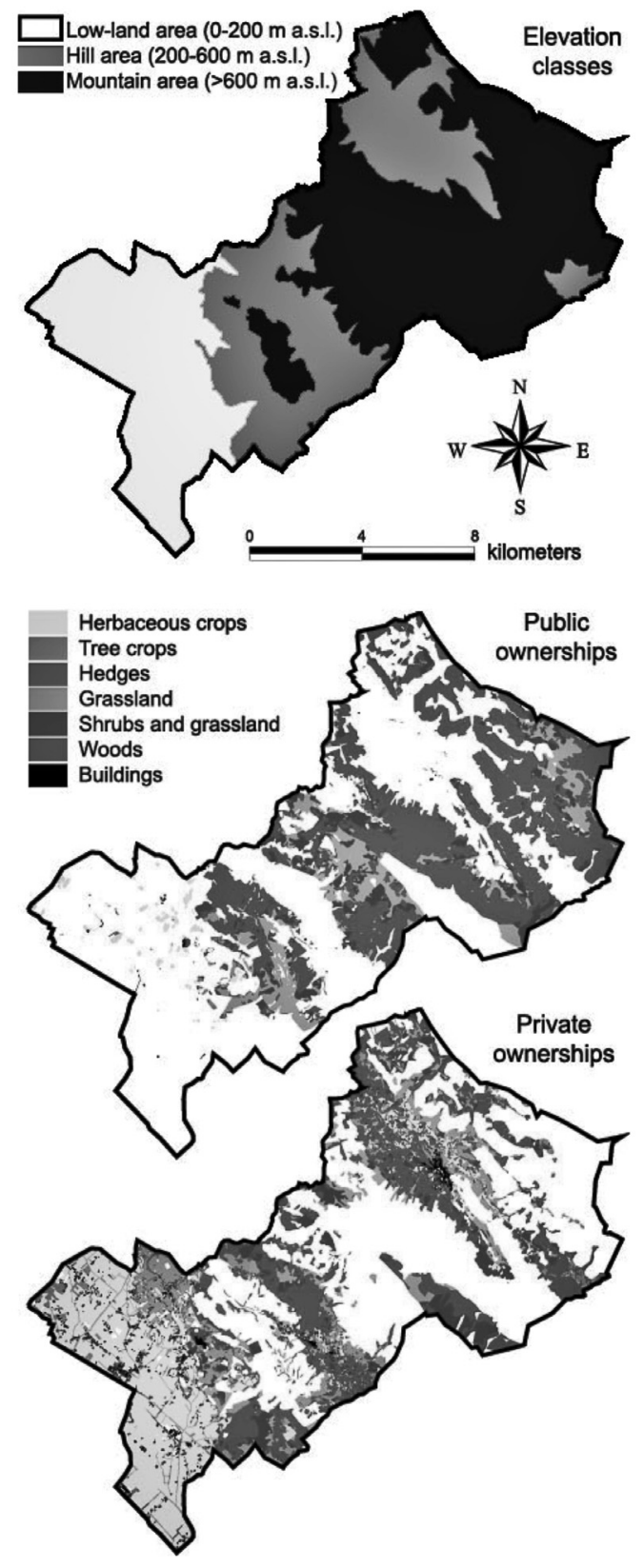

Figure 2. Elevation classes and land cover maps of private and public lands in the studied ecoregion.

land use potential correlates strongly with patterns of land ownership (Brown et al., 2000) we used an ecoregion classification which is hierarchically nested so that the ecoregion at the roughest scale is composed of two smaller ownership sub-systems (private $v s$ public lands), each with the above mentioned landscape complexes (Fig. 2).

All information was put into a database 
(number, area, perimeter of patches and length of linear elements) in order to select a core set of indexes and indicators suitable for evaluating both biodiversity and sustainability (Tab. 1).

\subsection{Statistical analysis}

The standard errors were calculated for mean patch size (MPS) and mean patch ecotone (MPE) on all land use classes. This information (which represents the standard deviation of the sampling) enables us to assess the statistical uncertainty of the various means, considering the ecoregion of this study as a representative sample of the landscape in Central Italy. The analysis of variance was performed on the diversity in terms of abundance $\left(\mathrm{H}^{\prime}\right)$ as indicated by Magurran (1988) in order to evaluate the differences between public and private land areas. According to Magurran (1988), the formula for calculating the variance of the estimator $\mathrm{H}^{\prime}\left(\operatorname{Var} \mathrm{H}^{\prime}\right)$ is:

$$
V a r H^{\prime} \approx \frac{\sum p_{i}\left(\ln p_{i}\right)^{2}-\sum_{N} p_{i}\left(p_{i} \ln p_{i}\right)^{2}}{2 N^{2}}
$$

where $p_{i}$ is the proportional abundance of the $\mathrm{i}^{\text {th }}$ vegetated landscape complex, $\mathrm{S}$ is the total number of vegetated landscape complexes in the ecoregion under study. $p_{i}$ is estimated as $n_{i} / N$, where $n_{i}$ is the number of patches in the $i^{\text {th }}$ vegetated landscape complex, $\mathrm{N}$ is the total number of patches, and $\ln$ is the natural logarithm

To test the null hypothesis on two Shannon diversity indices, the associated formula for calculating the $\mathrm{t}$-statistic $(t)$ for the t-test is:

$$
t=\frac{H_{1}^{\prime}-H_{2}^{\prime}}{\sqrt{\operatorname{VarH}_{1}^{\prime}-\operatorname{VarH}_{2}^{\prime}}}
$$

where $\mathrm{H}_{1}^{\prime}$ and $\mathrm{H}_{2}^{\prime}$ are the respective diversities of the two sites compared. The formula for calculating the degree of freedom $(d f)$ is:

$$
d f=\frac{\left(\operatorname{VarH}_{1}^{\prime}+\operatorname{VarH}_{2}^{\prime}\right)^{2}}{\left[\frac{\left(\operatorname{Var} H_{1}^{\prime}\right)^{2}}{N_{1}}\right]+\left[\frac{\left(\operatorname{Var} H_{2}^{\prime}\right)^{2}}{N_{2}}\right]}
$$

To reject the null hypothesis $\left(H_{0}: \mathrm{H}_{1}^{\prime}=\mathrm{H}_{2}^{\prime}\right)$, in favour of the alternative hypothesis $\left(H_{1}: \mathrm{H}_{1}^{\prime}\right.$ $\left.\neq \mathrm{H}_{2}^{\prime}\right)$, the tests compared the rejections of the null hypothesis to the level of significance $(\alpha)$ of the test for $1 \%, 5 \%$, and $10 \%$.

Table 1. List of the selected indicators and indexes for the analysis of patchiness and linear elements.

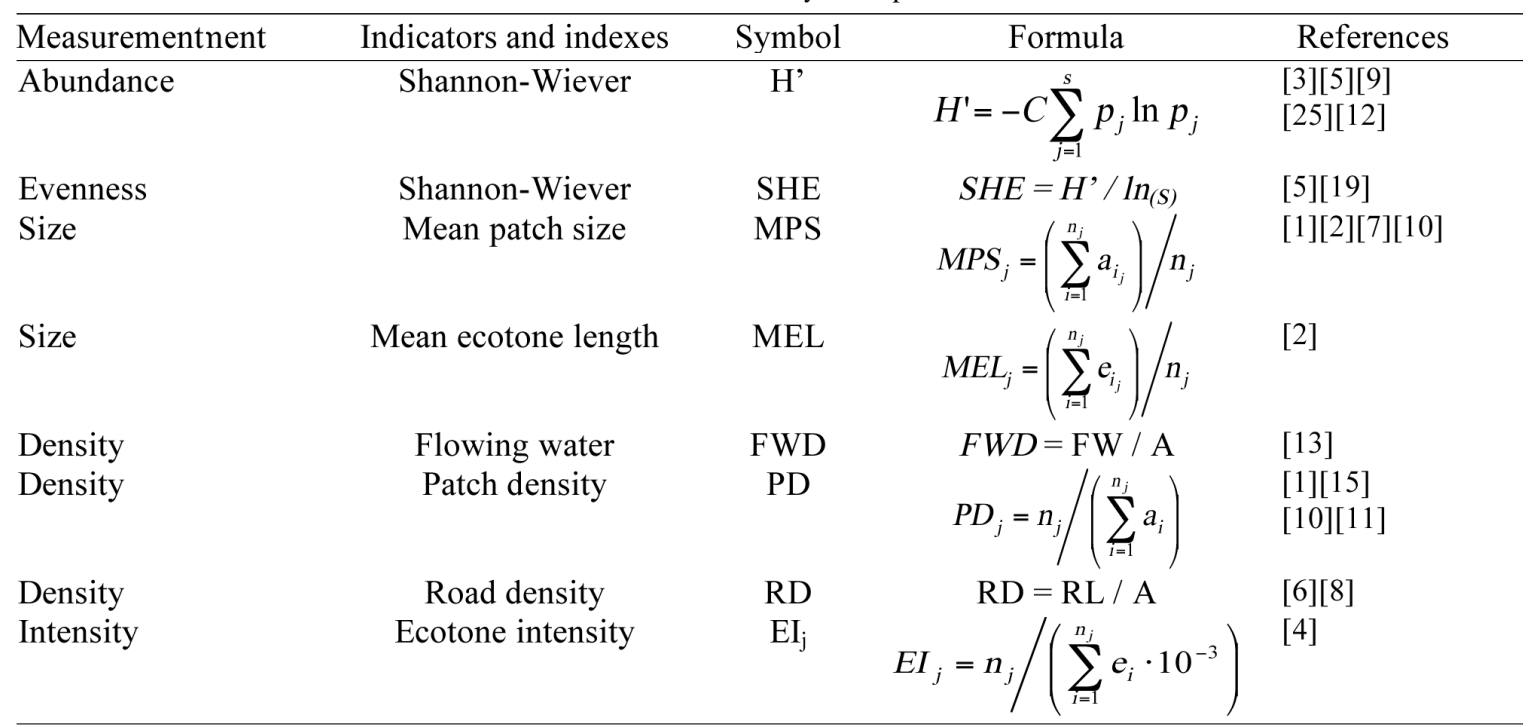

\section{Legend}

$\mathrm{A}=$ total area; $\mathrm{a}=$ patch's area; $\mathrm{e}=$ patch's perimeter; $\mathrm{i}=$ patch; $\mathrm{j}=$ landscape complexes; $\mathrm{n}=$ number of patches; $\mathrm{p}=$ area proportion of the land use class; FW = flowing water length in meters; RL = road length in meters; $\mathrm{s}=$ number of landscape complexes. 


\section{Results and discussion}

\subsection{Habitat fragmentation}

Habitat fragmentation concerns both habitat loss and spatial patterns of the residual fragments of habitat (Fahrig, 1997; Fahrig, 2003). The basic metrics (number, area, length) concerning the types of patches and the linear elements of the ecoregion are reported in Table 2. One of the meaningful indicators of habitat fragmentation is the ratio between the total area of the patches and their total number (i.e. mean patch size) (Tab. 3). Habitat fragmentation differs greatly with both elevation and ownership regime. In general the degree of habitat fragmentation decreases with elevation, but more consistently under the public ownership regime as shown by the relative values of MPS which are 0.53 ha (low-land), 4.01 ha (hill) and 8.95 ha (mountain) in public lands and 2.54 ha (lowland), 2.12 ha (hill) and 3.76 ha (mountain) in private lands. This also means that the native landscape habitat or biotope (wood habitat) is more preserved in mountain public areas and less in low-land private areas. In biodiversity strategies, the role of the wood patches is fun- damental also considering that the preservation and expansion of woodland may increase the probabilities of survival of the existing animal populations (Bailey, 2007). In the Italian climate, the woodlands represent the highest expression of vegetation complexity (the ecosystem with the highest biomass production) (Pignatti, 1997), and according to Bailey (2007) the semi-natural habitats near to woodland areas provide suitable conditions for woodland species. The average preservation rate values, expressed as percentage of wood patches on the total patch area of each class of elevation, are 59.6, 54.9 and 3.4 in mountain, hill and low-land areas, respectively (Tab. 2). In the mountain areas, the public wood patch / private wood patch area ratio is 3.3 and the mean wood patch size is 24.01 and 6.70 ha in the public and private lands, respectively (Tab. 3). This situation can be regarded as a heritage of the historical land use pattern, which corresponds to the ancient roman system ager-saltus-silva, or "field-pasture-forest", where farming, forestry, and animal husbandry were usually practiced on non-overlapping landscape units (Blondel and Aronson, 1995) within a gradient of elevation.

Table 2. Basic metrics (number, area and length) of patch types and linear elements in the ecoregion $($ pu = public ownership; $\mathrm{pr}=$ private ownership; $\mathrm{TV}=$ total vegetated).

\begin{tabular}{|c|c|c|c|c|c|c|c|c|c|c|}
\hline & \multicolumn{3}{|c|}{ Low-land } & \multicolumn{3}{|c|}{ Hill } & \multicolumn{3}{|c|}{ Mountain } & \multirow[t]{2}{*}{ Ecoregion } \\
\hline & $\overline{\mathrm{pu}}$ & $\mathrm{pr}$ & total & $\mathrm{pu}$ & $\mathrm{pr}$ & total & $\mathrm{pu}$ & $\mathrm{pr}$ & total & \\
\hline $\mathrm{HC}$ & 46 & 351 & 307 & 10 & numbe & 403 & 2 & 13 & 15 & 845 \\
\hline $\mathrm{TC}$ & 16 & 256 & 272 & 30 & 287 & 317 & 4 & 13 & 17 & $\begin{array}{l}843 \\
606\end{array}$ \\
\hline $\mathrm{W}$ & 8 & 69 & 77 & 73 & 233 & 306 & 142 & 153 & 295 & 678 \\
\hline $\mathrm{H}$ & 27 & 333 & 360 & 77 & 253 & 330 & 45 & 69 & 114 & 804 \\
\hline $\mathrm{G}$ & 2 & 166 & 168 & 39 & 172 & 211 & 177 & 160 & 337 & 716 \\
\hline SG & 8 & 114 & 122 & 90 & 166 & 256 & 218 & 139 & 357 & 735 \\
\hline B & 25 & 1531 & 1556 & 49 & 657 & 706 & 10 & 94 & 104 & 2366 \\
\hline TV & 107 & 1289 & 1396 & 319 & 1504 & 1823 & 588 & 577 & 1165 & 4384 \\
\hline Total & 132 & 2820 & 2952 & 368 & 2161 & 2529 & 598 & 671 & 1269 & 6750 \\
\hline $\mathrm{HC}$ & 21 & 2446 & 2467 & 5 & 359 & 364 & 3 & 56 & 59 & 2890 \\
\hline TC & 9 & 474 & 483 & 28 & 666 & 694 & 2 & 15 & 17 & 1194 \\
\hline $\mathrm{W}$ & 13 & 103 & 116 & 837 & 1646 & 2483 & 3410 & 1026 & 4436 & 7035 \\
\hline $\mathrm{H}$ & 3 & 41 & 44 & 9 & 40 & 49 & 8 & 15 & 23 & 116 \\
\hline $\mathrm{G}$ & 5 & 134 & 139 & 199 & 200 & 399 & 1140 & 557 & 1697 & 2235 \\
\hline SG & 5 & 80 & 85 & 203 & 283 & 486 & 698 & 506 & 1204 & 1775 \\
\hline B & 3 & 73 & 76 & 2 & 48 & 50 & 0 & 3 & 3 & 129 \\
\hline TV & 56 & 3278 & 3334 & 1281 & 3194 & 4475 & 5261 & 2174 & 7436 & 15245 \\
\hline Total & 59 & 3351 & 3410 & 1283 & 3242 & 4525 & 5261 & 2177 & 7439 & 15374 \\
\hline RL & 1 & 119 & 120 & 9 & 115 & 124 & 17 & 37 & 54 & 298 \\
\hline FW & 1 & 42 & 43 & 5 & 30 & 35 & 8 & 5 & 13 & 90 \\
\hline
\end{tabular}


Table 3. Mean patch size (MPS) and mean ecotone length (MEL) of the ecoregion land use classes (standard error values are reported in brackets).

\begin{tabular}{|c|c|c|c|c|c|c|c|c|c|c|}
\hline & \multicolumn{3}{|c|}{ Low-land } & \multicolumn{3}{|c|}{ Hill } & \multicolumn{3}{|c|}{ Mountain } & \multirow[t]{2}{*}{ Ecoregion } \\
\hline & $\overline{\mathrm{pu}}$ & $\mathrm{pr}$ & total & $\mathrm{pu}$ & pr & total & $\mathrm{pu}$ & pr & total & \\
\hline \multicolumn{11}{|l|}{$M P S$} \\
\hline $\mathrm{HC}$ & $0.46(0.11)$ & $6.97(1.04)$ & $6.22(0.92)$ & $0.45(0.28)$ & $0.91(0.07)$ & $0.90(0.07)$ & $1.35(0.57)$ & $1.30(0.22)$ & $1.30(0.21)$ & $3.42(0.44)$ \\
\hline $\mathrm{TC}$ & $0.55(0.17)$ & $1.85(0.22)$ & $1.78(0.21)$ & $0.92(0.23)$ & $2.32(0.26)$ & $2.19(0.24)$ & $0.60(0.02)$ & $1.12(0.31)$ & $1.00(0.24)$ & $1.97(0.16)$ \\
\hline W & $1.68(0.56)$ & $1.49(0.22)$ & $1.51(0.21)$ & $11.47(3.46)$ & $7.07(1.66)$ & $8.12(1.51)$ & $24.01(6.15)$ & $6.70(1.23)$ & $15.04(3.06)$ & $10.38(1.51)$ \\
\hline $\mathrm{H}$ & $0.13(0.02)$ & $0.12(0.01)$ & $0.12(0.01)$ & $0.12(0.01)$ & $0.16(0.01)$ & $0.15(0.01)$ & $0.19(0.02)$ & $0.21(0.02)$ & $0.20(0.01)$ & $0.14(0.01$ \\
\hline G & $2.49(0.45)$ & $0.81(0.09)$ & $0.83(0.09)$ & $5.09(1.73)$ & $1.16(0.16)$ & $1.89(0.36)$ & $6.44(1.51)$ & $3.48(0.53)$ & $5.04(0.84)$ & $3.12(0.41)$ \\
\hline SG & $0.59(0.16)$ & $0.70(0.10)$ & $0.70(0.10)$ & $2.26(0.41)$ & $1.71(0.34)$ & $1.90(0.27)$ & $3.20(0.39)$ & $3.64(0.71)$ & $3.37(0.36)$ & $2.42(0.20)$ \\
\hline TV & $0.53(0.08)$ & $2.54(0.30)$ & $2.39(1.04)$ & $4.01(0.57)$ & $2.12(0.40)$ & $2.45(0.23)$ & $8.95(0.43)$ & $3.76(0.48)$ & $6.37(0.83)$ & $3.48(0.26)$ \\
\hline \multicolumn{11}{|l|}{$M E L$} \\
\hline $\mathrm{HC}$ & $295(33)$ & 1221(102) & $1114(92)$ & $238(64)$ & $488(21)$ & $481(21)$ & $689(174)$ & $587(62)$ & $592(60)$ & $784(46)$ \\
\hline $\mathrm{TC}$ & $326(53)$ & $619(45)$ & $601(43)$ & $431(62)$ & 761(53) & $730(49)$ & $370(37)$ & $528(105)$ & $491(82)$ & $666(32)$ \\
\hline W & $1131(403)$ & $1192(116)$ & $1186(111)$ & $1757(368)$ & $1850(260)$ & $1828(216)$ & $2710(452)$ & $1586(186)$ & $2128(240)$ & $1885(144)$ \\
\hline $\mathrm{H}$ & 218(34) & $222(10)$ & $222(9)$ & 188(12) & $228(8)$ & 219(7) & $237(20)$ & 291(19) & $270(14)$ & $227(5)$ \\
\hline G & $724(53)$ & $985(96)$ & $982(95)$ & $1129(278)$ & $621(47)$ & $715(65)$ & $1416(215)$ & 1080(99) & $1257(123)$ & $1033(65)$ \\
\hline SG & $449(58)$ & $532(32)$ & $526(30)$ & $766(76)$ & $642(52)$ & $686(43)$ & $1043(78)$ & $949(81)$ & $1007(57)$ & $815(33)$ \\
\hline TV & $362(41)$ & $750(34)$ & $721(87)$ & $850(67)$ & $739(45)$ & $759(35)$ & 1491(71) & $1037(72)$ & $1266(74)$ & $881(28)$ \\
\hline
\end{tabular}

Local conditions of persistent summer drought, which are mitigated at higher elevation due to rainfall, induced shepherds to clear areas of forest in the mountains in order to obtain mountain pastures for seasonal grazing (transhumance) (Hobbs et al., 1995). Transhumance was a historical phenomenon which was important for the preservation of biodiversity (Olea and Mateo-Tomás, 2009), based on the seasonal movement of livestock between winter (valley) and summer (mountain) pastures (Grenon and Batisse, 1989; Hadjigeorgiou et al. 2005). This phenomenon brought about the landscape shift towards a pastoral / agrarian landscape pattern, which still exists today. Indeed, the grassland patches are the second most widespread landscape element in mountain areas and they cover $22.8 \%$, decreasing to $8.8 \%$ and $4.1 \%$ in the hilly and low-land areas, respectively (Tab. 2). In the mountain areas, the public grassland area / private grassland area ratio is 2.0 and the mean grassland patch areas are 6.44 and 3.48 ha in the public and private ownership regime, respectively (Tab. 3).

If we consider the amount of arable land habitat, as a cumulated area of $\mathrm{HC}$ and TC patches, it shows an opposite pattern compared to wood and grassland patches. The highest proportion of arable land $(86.5 \%)$ is in the low-land areas, while it decreases to 23.4 and $1.0 \%$ in the hilly and mountain areas, respectively (Tab. 2). The arable land habitat is generally found pri- vate ownership, where it is always more than $96 \%$ in both low-land and hill areas. The mean patch size of both HC and TC differs greatly with elevation and ownership, but the highest values were recorded in the private land: 6.97 ha for HC in the low-land areas and 2.32 ha for $\mathrm{TC}$ in the hilly areas.

The landscape element SG can be regarded as an indicator of recent agricultural abandonment due to agricultural intensification focused on more accessible higher quality land (typically closer to the farm-holding and sometimes characterized by the misuse of fertilizers, pesticides and herbicides producing negative environmental impacts, Mac Donald et al., 2000). The SG is the third most widespread landscape element in the mountain areas, where it covers $16.2 \%$ of the land, while it decreases to 10.7 and $2.5 \%$ in the hilly and low-land areas, respectively (Tab. 2). Its mean patch size is around 3.0 ha in mountain areas and 2.0 ha in hilly areas, both in private and public lands (Tab. 3 ).

The landscape element B, shows the intensity of human settlement. B patches are generally found in private lands while they are sporadic in all elevation classes $(2.2,1.1$, and $0.04 \%$ in low-land, hilly, and mountain areas, respectively). However it is much more consistent in terms of number of patches $(52.7,27.9$ and $8.2 \%$ in low-land, hilly and mountain areas, respectively) (Tab. 2). Numerous small B patches are relatively widespread especially in low-land and 
Ital. J. Agron. / Riv. Agron., 2010, 4:341-352

Table 4. Patch density (PD) and ecotone intensity (EI) of the ecoregion land use classes.

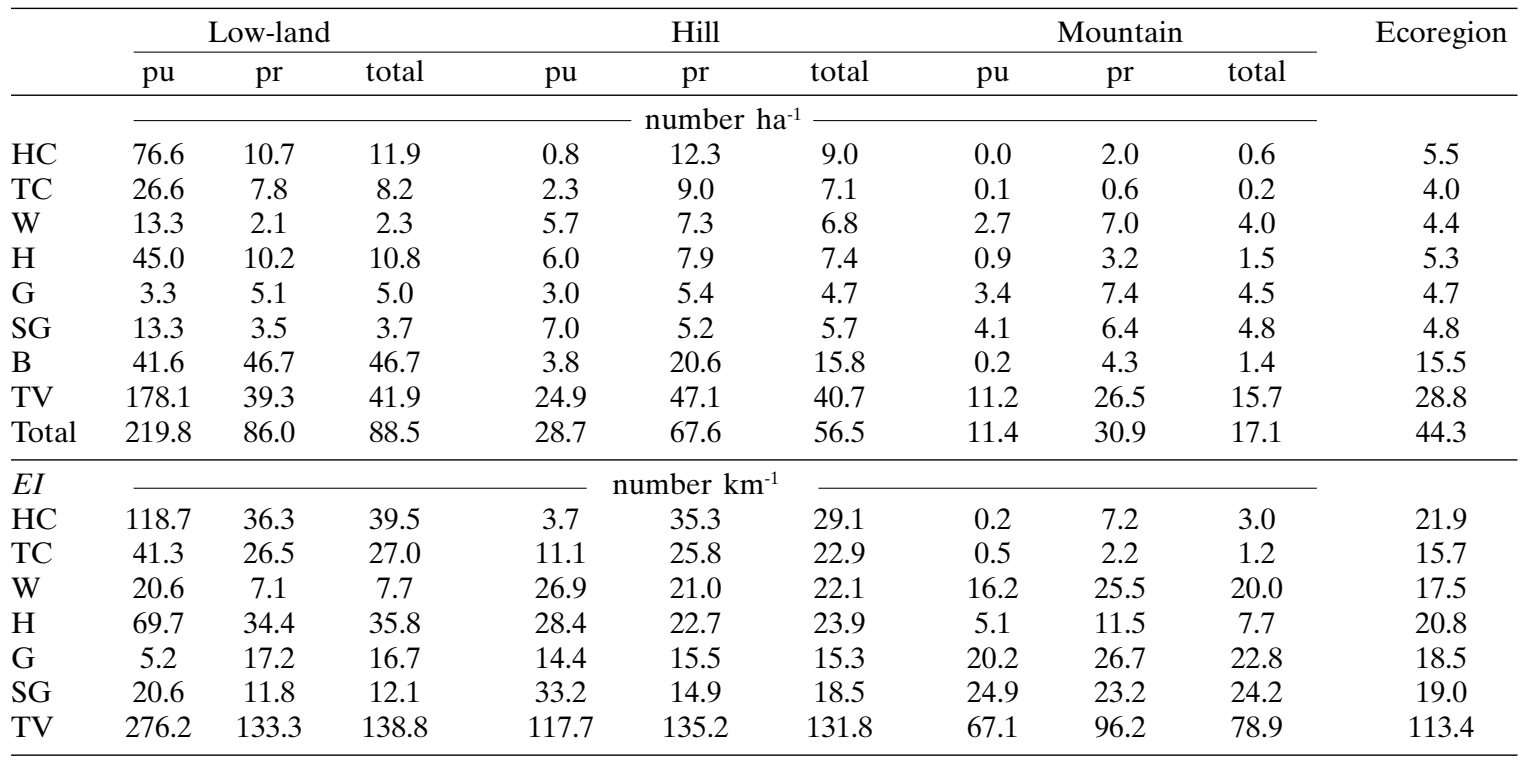

hilly areas, as shown by the values of B patch density which are 46.7, 15.8 and 1.4 building. 100 $\mathrm{ha}^{-1}$ in low-land, hilly and mountain areas, respectively (Tab. 4).

Roads, as linear elements that increase fragmentation, have generally a negative impact on environmental biodiversity but also provide communication facilities in order to manage and control the territory more efficiently and to facilitate energy and matter flows (Jaarsma and Willems, 2002). Roads intersect mainly low-land and hilly areas in private lands (Tab. 2) and their density (RD) decreases with elevation (35.2, 27.4 and $7.3 \mathrm{~m} \cdot \mathrm{ha}^{-1}$ in low-land, hilly and mountain areas, respectively).

The total length of the flowing waters (FW) of the ecoregion is about $90 \mathrm{~km}$ mainly located in the low-land areas - FWD is 12.6, 7.7 and 1.7 $\mathrm{m} \mathrm{ha}^{-1}$ in low-land, hilly and mountain areas, respectively - where the land was intensively reclaimed about 70 years ago.

The general pattern of habitat fragmentation shows the relationship between sustainability and the multiple driving forces of the more recent land-use changes. Within a local context such as the study area the topographical conditions are determinant for shaping human activity systems. The concentration of human population and related activities such as agriculture are mainly carried out in low-land areas. At these altitudes mobility is relatively easier to promote and natural resources are more con- centrated in terms of deeper and more fertile soils, more available water, and more biomass productivity, the latter is also a consequence of slight physical constraints, such as severe temperatures. As a result, habitat fragmentation is a more pronounced phenomenon at lower levels of elevation, while natural habitat and ecological integrity is better preserved at higher elevation. There is a paramount ecological meaning for preserving natural vegetation at higher elevation - such as that provided by woods because natural vegetation promotes a balance in the hydrologic cycle reducing runoff and soil erosion, and increasing water infiltration and plant productivity. The balance of the hydrologic cycle is the first condition necessary for ensuring land sustainability at catchment level. In this case study, the ownership regime reveals itself as a powerful driver for maintaining the original habitat such as woods in the more fragile zones, i.e. in mountain areas. Ever since medieval times, established local community institution, called "Università Agrarie", have been active in managing wood habitat as a renewable resource, through appropriate limitations to times and methods for cutting and harvesting timber and firewood. The demand of wood habitat in the mountain areas to be transformed into grassland for the seasonal grazing of sheep or into arable land could have reached the maximum level in the past due to anthropic pressure. Today, considering that around $60 \%$ is 
woodland and around $30 \%$ is permanently vegetated cover (grassland + shrub and grassland patches), around $90 \%$ of the fragile mountain areas is both productive and protective in order to provide a balance between ecological integrity and human requirements. The native wood habitat has been largely modified in the hill areas and almost completely in the low-land areas. In such extreme conditions, where naturalness or the ecological integrity of the original biotope has been modified in order to provide food and space for a more competitive ecosystem component such as human population, the challenge of sustainability is focused on the ability of human beings to maintain the ecological balance in new agro-ecosystems. In this frame agro-ecosystem biodiversity and environmentally friendly agricultural practices should compensate for habitat loss or naturalness consumption.

\subsection{Agro-ecosystem biodiversity and sustainability}

Some inference concerning biodiversity and sustainability can be drawn from our patchiness analysis by examining at landscape metrics such as patch evenness and ecotone density. The hilly areas are characterized by a more even patch pattern as expressed by Shannon-Wiener index values (Tab. 5), meaning that the land use classes in terms of covered area are more balanced in the hills than in the low-land and mountain areas. Balance in patchiness or habitat diversity is always an indicator of both ecological and aesthetical equilibrium. The appreciation of Mediterranean ecosystems, both in terms of biodiversity and sustainability, only refers to the mixed agro-sylvo-pastoral system that local people in different parts of the Mediterranean areas historically chose from the Middle ages to the middle of the 20th century (Blondel and
Aronson, 1995; Naveh, 1998). In the low-land area, the highest values (6.97 ha) of the HC patch size are recorded in the private land (Tab. 3 ), which is a clear landscape sign in the current agricultural context of intensive agricultural use carried out on large fields appropriate for mechanization and related practices (monoculture, fertilization, irrigation, chemical treatments, etc.). Over the last 50 years there has been a change in the use of agricultural land due to industrialization causing the re-arrangement of traditional small fields and their relative structure of spatial and temporal crop patterns (intercropping and complex crop rotation systems) into far larger fields cropped with monoculture plantations. As a result important temporary or permanent inter-field structures such as ditches, rows of tree-crops, and hedgerows have been largely reduced or have disappeared causing a decrease in both the environmental quality of local resources (e.g. soil and water) and biodiversity. As seen from the landscape patch analysis a good indirect indicator of biodiversity is the ecotone intensity (Tab. 4). Diversity in ecosystems can be observed and measured not only in terms of composition (species richness and distribution) but also as a variation in structure (growth form) and function (flow paths relative to system processes at the levels of scale) (Noss, 1990). Ecotone structures involving complex associations of plants such as hedgerows, are rich in all the above-mentioned elements of biodiversity. Hedgerows are vegetation structures that can be considered as the narrowest fragments of native wood biotope. Their values as landscape elements of higher diversity are largely acknowledged (Russell, 1989; Marshall and Moonen, 2002). In our case study, the mean $\mathrm{H}$ ecotone length does not greatly differ among the elevation classes ranging from 218 to $291 \mathrm{~m}$

Table 5. Landscape diversity in terms of abundance (H') and evenness (SHE) of the vegetated areas. The values of variance (var.), degree of freedom (d.f.) and t-test significant level (t-test) were reported.

\begin{tabular}{|c|c|c|c|c|c|c|c|c|c|c|}
\hline & \multicolumn{3}{|c|}{ Low-land } & \multicolumn{3}{|c|}{ Hill } & \multicolumn{3}{|c|}{ Mountain } & \multirow{2}{*}{ Ecoregion } \\
\hline & $\mathrm{pu}$ & $\mathrm{pr}$ & total & $\mathrm{pu}$ & $\mathrm{pr}$ & total & $\mathrm{pu}$ & $\mathrm{pr}$ & total & \\
\hline $\mathrm{H}^{\prime}$ & 1.589 & 0.883 & 0.903 & 0.998 & 1.357 & 1.326 & 0.898 & 1.204 & 1.010 & 1.441 \\
\hline $\begin{array}{l}\text { Var. } \\
\text { d.f. } \\
\text { t-test }\end{array}$ & 0.0057 & $\begin{array}{c}0.0004 \\
64 \\
* * *\end{array}$ & 0.0004 & 0.0006 & $\begin{array}{c}0.0002 \\
2187 \\
* * *\end{array}$ & 0.0002 & 0.0001 & $\begin{array}{c}0.0002 \\
4130 \\
* * *\end{array}$ & 0.0001 & \\
\hline SHE & 0.887 & 0.493 & 0.504 & 0.557 & 0.757 & 0.740 & 0.501 & 0.672 & 0.564 & 0.804 \\
\hline
\end{tabular}

$* * *$ significant level at $\mathrm{P} \leq 0.001$. 
(Tab. 3). The $\mathrm{H}$ ecotone intensity is high in the low-land areas $(\mathrm{PD}=10.8 ; \mathrm{EI}=35.8)($ Tab. 4). The $\mathrm{H}$ ecotone intensity ratio between the lowland area and the other two elevation classes is 1.5 and 4.7 for the hill and mountain areas, respectively.

In this case, greater $\mathrm{H}$ ecotone abundance is a factor of biodiversity which compensates in the low-land area for the loss of habitat of the native biotope. It is interesting to note that the same trend of decreasing ecotone intensity from low-land to mountain areas, found in hedgerows, is also seen for the two components (HC and TC) of arable land. In terms of agricultural sustainability, the permanence of hedgerows next to field crops is recently seen as an important element of biodiversity, biological control of crop pests and diseases, and biological barriers against water eutrophication and air pollution (Millán de la Peña et al., 2003; Bates and Harris, 2009).

Unfortunately, this study could present two main limits. The first limit is related to the space characteristics of the analysed system in terms of the type of borders (municipality borders often are disconnected from ecological patterns) and in terms of the absence of other ecoregions (analyzed with the same methodology) for comparison. The second limit is related to the fact that the analysis was carried out in a single period of time. If a temporal analysis was carried out at different times the results of this evolution could be similar to the results of other studies (in Central Italy) with a sharp increase in woodlands and drastic decreases in arable land, pastures and mixed cultivations (Agnoletti, 2007). Otherwise the benefits of research are related to the ease of application and use of information by decision makers.

\section{Conclusions}

An ecological enquiry at landscape level can improve the human capacity for monitoring and evaluating land-use patterns in view of enhancing the sustainability of human activity systems. In this case study, landscape metrics based on habitat patch diversity provided a profile of an ecoregion in Central Italy, where historical landuse patterns are still present on the territory and testify the capacity of human beings for devel- oping a balanced relationship with their context of life at local level. Even if recent changes in society trends bring about more demographic pressure and more environmentally-aggressive technological fixes, traditional land use patterns transferred from generation to generation through culture, education, regulations and action at local level, can help mitigate human impact and operate as a cultural buffer for ecosystem resilience. In general, a new science of sustainability should rely on gaining knowledge directly from local solutions of land-use patterns established by intergenerational wisdom. Decision makers need instruments in order to achieve sustainable development and in this research useful tools (easy to understand, to communicate, and to repeat) were proposed and applied.

In an ecoregion where almost $48 \%$ of the territory is mountain, about $30 \%$ is hilly and only about $22 \%$ is low-land, an important factor for ensuring sustainability in land use is to protect the soil against erosion while keeping water on the spot to operate positively in promoting biomass accumulation and use through agro-forestry practices. Around $90 \%$ of the mountain area is currently covered with permanent natural vegetation - wood, shrub, and grassland -, which guarantees protection against runoff and an adequate stocking of precipitation for ecosystem productivity and services at local and regional level. This situation is an evident outcome of a historical land - management system based on public property - currently more than $70 \%$ - of the mountain land. In the hilly areas, where the public land decreases to around $28 \%$, a more balanced patch pattern is achieved by replacing woods and grasslands with agricultural land in moderation. In this area, higher values of habitat patch diversity are a consequence of a mixed agro-sylvo-pastoral use of land which has been established for centuries as a manifest sign of co-evolutionary development between human settlement requirements and provision of ecological services by natural ecosystem components and processes.

In the low-lands, there is more anthropic pressure and private property dominates. Agricultural land reaches the maximum extension, with large fields of herbaceous crops (mean patch size in private lands $=6.97 \mathrm{ha}$ ) while wood 
patches account for only $3 \%$ of land use. Naturalness consumption in low lands is at its maximum, as well as agricultural productivity which is boosted by more favourable environmental conditions. The maintenance of agroecosystem sustainability in low lands is a matter of agrobiodiversity conditions both among crop fields and within crop fields. A landscape analysis can supply useful information about the former condition, as shown in this case study by landscape metrics such as hedge ecotone density. Concerning the latter, a more detailed enquiry at both farming and cropping system level is required in order to determine if agricultural cropping system design and management is suitable for maintaining soil fertility and the quality of biotic and abiotic natural resources, which are the basis for agricultural production as well as for life in general. In order to improve the quality of this kind of research activity in landscape ecology an extension of time and space borders of the system are required. The time extension refers to an analysis of a sequence of images separated by a sufficient amount of time in order to find significant changes in land cover (e.g. 10 years). The space extension refers to an increase of the casuistry (number of ecoregions analysed) in order to compare their results. Even if the indicators used are appropriate for analyzing the landscape, other investigative tools can be added in order to improve the research.

\section{Acknowledgment}

The authors would especially like to thank Bosa Bachisio and Claudio Stefanoni for their invaluable help with the field work required for this study.

\section{References}

Agnoletti M. 2007. The degradation of traditional landscape in a mountain area of Tuscany during the $19^{\text {th }}$ and $20^{\text {th }}$ centuries: implications for biodiversity and sustainable management. Forest. Ecol. Manag., 249:5-17.

Bates F.S., Harris S. 2009. Does hedgerow management on organic farms benefit small mammal populations? Agric. Ecosyst. Environ., 129:124-130.

Bailey S. 2007. Increasing connectivity in fragmented landscapes: an investigation of evidence for biodiversity gain in woodlands. Forest. Ecol. Manag., 238:2-23.

Bastin G.N., Ludwig J.A., Eager R.W., Chewings V.H.,
Liedloff A.C. 2002. Indicators of landscape function: comparing patchiness metrics using remotely-sensed data from rangelands. Ecol. Indic., 1:247-260.

Blondel J., Aronson J. 1995. Biodiversity and ecosystem function in the Mediterranean basin: human and nonhuman determinants. In: Davis G.W., Richardson D.M., (eds): Mediterranean-type ecosystems: the Function of biodiversity. Springer-Verlag, Berlin, 43119.

Brown D.G., Pijanowski B.C., Duh J.D. 2000. Modelling the relationships between land-use and land-cover on private lands in the Upper Midwest, USA. J. Environ. Manage., 59:247-263.

Busch G. 2006. Future European agricultural landscapes - what can we learn from existing quantitative land use scenario studies? Agric. Ecosyst. Environ., 114:121- 140.

Burel F., Baudry J. 2003. Landscape ecology: concepts, methods and applications. Science Publishers Inc., Enfield (NH), pp. 362.

Caporali F. 2004. Agriculture and health: the challenge of organic farming. Editeam, Cento (FE), pp. 252.

Caporali F., Mancinelli R., Campiglia E. 2003. Indicators of cropping system diversity in organic and conventional farms in Central Italy. Int. J. Agric. Sustainability, 1:67-72.

Caporali F., Campiglia E., Mancinelli R. 2010. Agroecologia: teoria e pratica degli agroecosistemi. UTETLibreria, Torino, pp. 322.

Daily G.C. 1997. Nature' services: societal dependence on natural ecosystems. Island Press, Washington, pp. 412.

Duelli P. 1997. Biodiversity evaluation in agricultural landscapes: an approach at two different scales. Agric. Ecosyst. Environ., 62:81-91.

Elkie P., Rempel R., Carr A. 1999. Patch analyst user's manual. Ontario Ministry Natural Resources, Northwest Science and Technology, Thunder Bay, pp. 23.

European Commission 2005. Trends of some agri-environmental indicators in the European Union: report EUR 21565 EN. European commission, Joint Research Centre, Bruxelles.

Fahrig L. 1997. Relative effects of habitat loss and fragmentation on population extinction. J. Wildl. Manage., 61:603-610.

Fahrig L. 2003. Effects of habitat fragmentation on biodiversity. Annu. Rev. Ecol. Evol. Syst., 34:487-515.

Forman R.T.T. 1995a. Some general principles of landscape and regional ecology. Landscape Ecol., 10:133142 .

Forman R.T.T. 1995b. Land mosaics: the ecology of landscapes and regions. Cambridge University Press, Cambridge, pp. 632.

Grenon M., Batisse M. 1989. Futures for the Mediterranean basin: the blue plan. Oxford University Press, Oxford, pp. 279. 
Gustafson E.J. 1998. Quantifying landscape spatial pattern: what is the state of the art? Ecosystems, 1:143156.

Hadjigeorgiou I., Osoro K., Fragoso de Almeida J.P., Molle G. 2005. Southern European grazing lands: production, environmental and landscape management aspects. Livest. Prod. Sci., 96:51-59.

Hampicke U. 2006. Efficient conservation in Europe's agricultural countryside: rationale, methods and policy reorientation. Outlook Agr., 35:97-105.

Hargis C.D., Bissonette J.A., David J.L. 1998. Thebehavior of landscape metrics commonly used in the study of habitat fragmentation. Landscape Ecol., 13:167-186.

Henle K., Alard D., Clitherow J., Cobb P., Firbank L., Kull T., McCracken D., Moritz R.F.A., Niemelä J., Rebane M., Wascher D., Watt A., Young J. 2008. Identifying and managing the conflicts between agriculture and biodiversity conservation in Europe - a review. Agric. Ecosyst. Environ., 124:60-71.

Hobbs R.J., Richardson D.M., Davis G.W. 1995. Mediterranean-type ecosystems: opportunities and constraints for studying the function of biodiversity. In: Davis G.W., Richardson D.M. (eds): Mediterraneantype ecosystems: The function of biodiversity. Springer-Verlag, Berlin, 1-42.

Jaarsma C.F., Willems G.P.A. 2002. Reducing habitat fragmentation by minor rural roads through traffic calming. Landscape Urban. Plan., 58:125-135.

Li H., Wu J. 2004. Use and misuse of landscape indices. Landscape Ecol., 19:389-399.

Magurran A.E. 1988. Ecological diversity and its measurement. Princeton University Press, Princeton, pp. 192.

Maran T. 2000. Biodiversity. In: Fammler H., Veidemane K., Ruskule A., Simanovska J., Indriksone D., Kipper K. (eds): 2nd Baltic state of the environment report: based on environmental indicators. Baltic Environmental Forum. Gandrs Ltd., Riga, 113-123.

Marshall E.J.P., Moonen A.C. 2002. Field margins in northern Europe: their functions and interactions with agriculture. Agric. Ecosyst. Environ., 89:5-21.

McCarigal K., Cushman S.A., Neel M.C., Ene E. 2002. FRAGSTATS: spatial pattern analysis program for categorical maps, version 3.0. University of Massachusetts: computer software program produced by the authors at the University of Massachusetts, Amherst. www.umass.edu/landeco/research/fragstats/fragstats. html.

Mac Donald D., Crabtree J.R., Wiesinger G., Dax T., Stamou N., Fleury P., Gutierrez Lazpita J., Gibon A. 2000. Agricultural abandonment in mountain areas of Europe: environmental consequences and policy response. J. Environ. Manage., 59:47-69.

Millán de la Peña N., Butet A., Delettre Y., Morant P., Burel F. 2003. Landscape context and carabid beetles (Coleoptera: Carabidae) communities of hedgerows in western France. Agric. Ecosyst. Environ., 94:59-72.
Naveh Z. 1998. From biodiversity to ecodiversity: holistic conservation of the biological and cultural diversity of Mediterranean landscapes. In: Rundel P.W., Montenegro G., Jaksik F.M. (eds.): Landscape disturbance and biodiversity in Mediterranean-type ecosystems. Springer, Berlin, 23-53.

Noss R.F. 1990. Indicators for monitoring biodiversity: a hierarchical approach. Conserv. Biol., 4:355-364.

Nationale Rural Network, 2009. Rural territory national atlas: new areas and characteristics for rural development policies. MiPAAF-CAIRE, pp. 90.

OECD, 2001. Valuation of biodiversity benefits: selected studies. Organization for Economic Co-operation and Development, Paris, pp. 192.

Olea P.P., Mateo-Tomás P. 2009. The role of traditional farming practices in ecosystem conservation: the case of transhumance and vultures. Biol. Conserv., 142:1844-1853.

Omernik J.M. 1987. Ecoregions of the conterminous United States:map (scale 1:7,500,000). Ann. Assoc. Am. Geogr., 77:118-125.

Pickett S.T.A., Cadenasso M.L. 1995. Landscape ecology: spatial heterogeneity in ecological systems. Science, 269:331-334.

Pielou E.C. 1975. Ecological diversity. Wiley, New York, pp. 165.

Pignatti S. 1997. Ecologia del paesaggio. Edizioni UTET, Torino, pp. 238.

Ries L., Fletcher R.J., Battin J., Sisk T.D. 2004. Ecological responses to habitat edges: mechanisms, models, and variability explained. Annu. Rev. Ecol. Evol. Syst., 35:491-522.

Russell E.P. 1989. Enemies hypothesis: a review of the effect of vegetational diversity on predatory insects and parasitoids. Environ. Entomol., 18:590-599.

Rutledge D. 2003. Landscape indices as measures of the effects of fragmentation: can pattern reflect process? Department of Conservation, Science Internal Series 98, Wellington, pp. 27.

Ryszkowki L., Bartoszewics A., Kedziora A. 1999. Management of matter fluxes by biogeochemical barriers at the agricultural landscape level. Landscape Ecol., 14:479-492.

Saura S., Martinez-Millan J. 2001. Sensitivity of landscape pattern metrics to map spatial extent. Photogramm. Eng. Rem. S., 67:1027-1036.

Sevink J., Remmelzwaal A., Spaargaren O.C. 1984. The soil of southern Lazio and adjacent Campania. Universiteit van Amsterdam, Amsterdam, pp. 140.

Shannon C.E., Weaver W. 1949. The mathematical theory of communication. University of Illinois Press, Urbana-Champaign, pp. 144.

Tscharntke T., Steffan-Deventer I., Kruess A., Thies C. 2002. Contribution of small habitat fragments to conservation of insect communities of grassland-cropland landscapes. Ecol. Appl., 12:354-363. 
Turner M.C. 2003. Landscape ecology: what is the state of science? Annu. Rev. Ecol. Evol. Syst., 36:319-344.

UN, 1992. Agenda 21: program for action for sustainable development. United Nations, New York.

UNEP, 2001. Indicators and environmental impact assessment: designing national-level monitoring and in- dicator programmes, (United Nations Environment Programme) UNEP/CBD/SBSTTA/7/12, Subsidiary body on scientific, technical and technological advice, www.biodiv.org (accessed July 2008).

Xu D., Feng Z., Allen L.J.S., Swihart R.K. 2006. A spatially structured metapopulation model with patch dynamics. J. Theor. Biol., 239:469-481. 